\title{
Out-of-hospital cardiac arrest prognosis during the COVID-19 pandemic
}

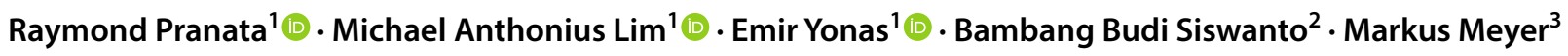

Received: 8 June 2020 / Accepted: 27 June 2020 / Published online: 9 July 2020

(c) Società Italiana di Medicina Interna (SIMI) 2020

\section{Dear Editor,}

Since the outbreak of coronavirus disease 2019 (COVID19), many health-care providers have urged patients to limit or delay non-urgent visits to minimize the risk of transmission. Despite these efforts, some health-care services have experienced an ever increasing volume of traffic. As healthcare providers are prioritizing emergency and COVID-19 cases, the majority of elective procedures have been postponed indefinetly. During the COVID-19 pandemic, there has been up to $48 \%$ reduction in acute myocardial infarctionrelated hospitalization [1]. A study by Hammad et al. in patients with ST-segment elevation myocardial infarction showed that $27 \%$ of patients avoided hospitals due to fear of COVID-19 transmission, 18\% thought that the symptoms were related to COVID-19, and 9\% did not want to burden the hospital [2]. Patients that did not seek medical attention may experience higher out-of-hospital-related complications, including out-of-hospital cardiac arrest (OHCA). Cardiopulmonary resuscitation (CPR) hypothetically carries the risk of COVID-19 transmission and may reduce willingness

Markus Meyer: SCOPUS ID: 55463410800.

Raymond Pranata

raymond_pranata@hotmail.com

Michael Anthonius Lim

lim.michael.a@gmail.com

Emir Yonas

e_yonas@windowslive.com

Markus Meyer

markus.meyer360@gmail.com

1 Faculty of Medicine, Universitas Pelita Harapan, Tangerang, Indonesia

2 Department of Cardiology and Vascular Medicine, Faculty of Medicine Universitas Indonesia, National Cardiovascular Center Harapan Kita, Jakarta, Indonesia

3 Faculty of Medicine, Universitas Indonesia, Jakarta, Indonesia to perform CPR without personal protective equipment [3]. Bystanders with advanced age and comorbidities who are at risk for severe infection might be discouraged even more [4-9]. We aimed to assess the effect of the COVID-19 pandemic on the characteristics, circumstances, and prognosis of OHCA.

We performed a systematic literature search from PubMed and medRvix from inception up until 5 June 2020 using the keyword ("cardiac arrest" AND ("COVID-19" OR "SARS-CoV-2" OR "2019-nCov" OR "pandemic")). The inclusion criteria were studies that compared OHCA in 2020 to previous years and reported any of the following: (1) proportion of out-of-hospital mortality, (2) proportion of unwitnessed cardiac arrest, (3) proportion of bystander CPR, or (4) proportion of shockable rhythm. We excluded studies without key outcomes, case reports, and articles without primary data. Statistical analysis was performed using RevMan 5.3 (Cochrane Collaboration). Odds ratios (ORs) were calculated using the Mantel-Haenszel formula with the random-effects model regardless of heterogeneity. There were 148 results, 140 of which were excluded through title and abstract screening. Full-text articles from the remaining eight records were assessed. We excluded six articles because of (1) cardiac events in general $(n=1),(2)$ insufficient data for analysis $(n=3)$, and (3) assessing transmission to medical personnel $(n=2)$. Two studies were included in the quantitative synthesis $[10,11]$.

For analysis, 883 OHCA patients from the pandemic in 2020 were included; the comparator group included 2019 (Baldi et al., Italy) and weeks 12-17 of each year from 2012 to 2019 (Marijon et al., France). The total number of OHCA cases was higher in the year 2020 (883 vs. 764) compared to 2019. During the pandemic, out-of-hospital mortality was higher (OR $2.07[1.65,2.61], p<0.001 ; I^{2}: 0 \%, p=0.60$ ) (Fig. 1). The rate of unwitnessed cardiac arrest was higher (OR $1.36[1.15,1.61], p<0.001 ; I^{2}: 0 \%, p=0.32$ ) during the pandemic and the rates of bystander CPR (OR 0.52 $\left.[0.43,0.62], p<0.001 ; I^{2}: 0 \%, p=0.99\right)$ and shockable 


\begin{tabular}{|c|c|c|c|c|c|c|c|c|c|}
\hline $\begin{array}{l}\text { A. Mortality } \\
\text { Study or Subgroup }\end{array}$ & \multicolumn{2}{|c|}{ Pandemic } & \multicolumn{2}{|c|}{ Non-Pandemic } & Weight & $\begin{array}{c}\text { Odds Ratio } \\
\text { M-H, Random, } 95 \% \mathrm{Cl}\end{array}$ & \multicolumn{3}{|c|}{$\begin{array}{c}\text { Odds Ratio } \\
\text { M-H, Random, } 95 \% \mathrm{Cl}\end{array}$} \\
\hline Baldi 2020 & 321 & 362 & 177 & 229 & $26.6 \%$ & $2.30[1.47,3.60]$ & & - & \\
\hline Marijon 2020 & 454 & 521 & 2357 & 3052 & $73.4 \%$ & $2.00[1.53,2.62]$ & & & \\
\hline Total $(95 \% \mathrm{Cl})$ & & 883 & & 3281 & $100.0 \%$ & $2.07[1.65,2.61]$ & & $\nabla$ & \\
\hline Total events & 775 & & 2534 & & & & & & \\
\hline \multicolumn{6}{|c|}{$\begin{array}{l}\text { Heterogeneity: } \text { Tau }^{2}=0.00 ; \mathrm{Chi}^{2}=0.28, \mathrm{df}=1(P=0.60) ; I^{2}=0 \% \\
\text { Test for overall effect: } Z=6.18(P<0.00001)\end{array}$} & & $\begin{array}{c}0.1 \\
\text { Favours [Pandemic] }\end{array}$ & $\begin{array}{cc} & 1 \\
& 10 \\
\text { Favours [Non-Pandemic }\end{array}$ & 100 \\
\hline $\begin{array}{l}\text { B. Unwitnessed } \\
\text { Study or Subgroup }\end{array}$ & \multicolumn{2}{|c|}{ Pandemic } & \multicolumn{2}{|c|}{ Non-Pandemic } & Weight & Odds Ratio & \multicolumn{3}{|c|}{$\begin{array}{l}\text { Odds Ratio } \\
\text { M-H, Random, } 95 \% \mathrm{Cl}\end{array}$} \\
\hline Baldi 2020 & 199 & 362 & 100 & 229 & $25.2 \%$ & $1.57[1.13,2.20]$ & & $\rightarrow-$ & \\
\hline Marijon 2020 & 206 & 500 & 1021 & 2908 & $74.8 \%$ & $1.29[1.07,1.57]$ & & & \\
\hline Total $(95 \% \mathrm{Cl})$ & & 862 & & 3137 & $100.0 \%$ & $1.36[1.15,1.61]$ & & $\bullet$ & \\
\hline Total events & 405 & & 1121 & & & & & & \\
\hline $\begin{array}{l}\text { Heterogeneity: } \operatorname{Tau}^{2}=0 \\
\text { Test for overall effect: } Z\end{array}$ & $\begin{array}{l}.00 ; \mathrm{Chi}^{2} \\
=3.60\end{array}$ & $\begin{array}{l}=0.99 \\
=0.0\end{array}$ & $\begin{array}{l}\mathrm{df}=1(\mathrm{P}= \\
003)\end{array}$ & $0.32) ; I^{2}$ & ${ }^{2}=0 \%$ & & $\begin{array}{l}0.1 \\
\text { Favours [Pandemic] }\end{array}$ & 1 Favours [Non-Pandemic] & ${ }_{100}^{100}$ \\
\hline $\begin{array}{l}\text { C. Bystander CPR } \\
\text { Study or Subgroup }\end{array}$ & $\begin{array}{l}\text { Panden } \\
\text { Events }\end{array}$ & $\begin{array}{l}\text { nic } \\
\text { Total }\end{array}$ & $\begin{array}{l}\text { Non-Panc } \\
\text { Events }\end{array}$ & $\begin{array}{l}\text { emic } \\
\text { Total }\end{array}$ & Weight & $\begin{array}{l}\text { Odds Ratio } \\
\text { M-H, Random, } 95 \% \mathrm{Cl}\end{array}$ & $\begin{array}{r}\text { Odds } \\
\text { M-H, Ranc }\end{array}$ & $\begin{array}{l}\text { s Ratio } \\
\text { dom, } 95 \% \mathrm{Cl}\end{array}$ & \\
\hline Baldi 2020 & 59 & 188 & 63 & 134 & $16.0 \%$ & $0.52[0.33,0.82]$ & & & \\
\hline Marijon 2020 & 239 & 500 & 1165 & 1822 & $84.0 \%$ & $0.52[0.42,0.63]$ & & & \\
\hline Total $(95 \% \mathrm{Cl})$ & & 688 & & 1956 & $100.0 \%$ & $0.52[0.43,0.62]$ & & & \\
\hline Total events & 298 & & 1228 & & & & & & \\
\hline $\begin{array}{l}\text { Heterogeneity: } \operatorname{Tau}^{2}=0 \\
\text { Test for overall effect: } Z\end{array}$ & $\begin{array}{l}0.00 ; \mathrm{Chi}^{2} \\
=7.07(\mathrm{~F}\end{array}$ & $\begin{array}{l}=0.00 \\
><0.0\end{array}$ & $\begin{array}{l}\text { df }=1(P= \\
0001)\end{array}$ & $0.99) ; I^{2}$ & $2=0 \%$ & & $\begin{array}{ll}0.01 & 0.1 \\
\quad \text { Favours [Non-Pandemic] }\end{array}$ & 1 Favours [Pandemic] & 100 \\
\hline D. Shockable Rhythm & Panden & & Non-Pand & emic & & Odds Ratio & Odds & s Ratio & \\
\hline Study or Subgroup & Events & Total & Events & Total & Weight & $\mathrm{M}-\mathrm{H}$, Random, $95 \% \mathrm{Cl}$ & M-H, Ranc & dom, $95 \% \mathrm{Cl}$ & \\
\hline Baldi 2020 & 23 & 230 & 27 & 159 & $22.2 \%$ & $0.54[0.30,0.99]$ & & & \\
\hline Marijon 2020 & 46 & 500 & 474 & 2471 & $77.8 \%$ & $0.43[0.31,0.59]$ & & & \\
\hline Total $(95 \% \mathrm{Cl})$ & & 730 & & 2630 & $100.0 \%$ & $0.45[0.34,0.60]$ & & & \\
\hline Total events & 69 & & 501 & & & & & & \\
\hline $\begin{array}{l}\text { Heterogeneity: } \operatorname{Tau}^{2}=0 \\
\text { Test for overall effect: } Z\end{array}$ & $\begin{array}{l}0.00 ; \mathrm{Chi}^{2} \\
=5.55(\mathrm{~F}\end{array}$ & $\begin{array}{l}=0.49 \\
><0.0\end{array}$ & $\begin{array}{l}\mathrm{df}=1(P= \\
0001)\end{array}$ & $0.48) ; I^{2}$ & $2=0 \%$ & & $\begin{array}{ll}0.01 & 0.1 \\
& \text { Favours [Non-Pandemic] }\end{array}$ & $\stackrel{10}{1} \begin{array}{c}10 \\
\text { Favours [Pandemic] }\end{array}$ & 100 \\
\hline
\end{tabular}

Fig. 1 Meta-analysis of characteristics, circumstances, and prognosis of OHCA. Forest plots showing mortality (a), unwitnessed cardiac arrest (b), bystander CPR (c), and shockable rhythm (d). CPR cardiopulmonary resustication, OHCA out-of-hospital cardiac arrest

rhythm were lower (OR $0.45[0.34,0.60], p<0.001 ; I^{2}: 0 \%$, $p=0.48)$.

There are several explanations for increased OHCAassociated mortality during the pandemic; the first is due to increased unwitnessed cardiac arrest, as shown in the metaanalysis. Due to a stay at home order during this time, people who live alone are at higher risk of unwitnessed cardiac events. Unwitnessed cardiac arrest prolonged the time from collapse to CPR, which is associated with poorer outcomes [12]. Second, the rate of bystander CPR was halved compared to the non-pandemic period; the looming possibility of COVID-19 transmission may cause hesitancy to perform CPR. Waiting for emergency medical services to arrive to perform CPR causes delays, and resuscitation might be futile in some cases. Third, the rate of shockable rhythm was lower during the pandemic. Initial non-shockable rhythms generally have a poorer prognosis compared to shockable rhythms [13]. Prolonged time to shock delivery also leads to worsened prognosis [13]. Fourth, emergency medical service arrival time was also delayed, with a median of 15 min vs. $12 \mathrm{~min}$ in the Baldi et al. study and $10.4 \mathrm{~min}$ vs. $9.4 \mathrm{~min}$ in the study by Marijon et al. [10, 11]. Hesitant bystanders, along with delayed emergency medical services arrival, prolongs the time from collapse to CPR and time to shock delivery. The combination of these factors leads to a poor prognosis.

In conclusion, the COVID-19 pandemic was associated with higher OHCA-related mortality. The numbers might be even higher in developing countries due to poor health-care and emergency medical service systems.

Funding None. 


\section{Compliance with ethical standards}

Conflict of interest The author declares that they have no conflict of interest.

Human and animal rights This article does not contain any studies with human participants or animals performed by any of the authors.

Informed consent No informed consent is required.

\section{References}

1. De Rosa S, Spaccarotella C, Basso C et al (2020) Reduction of hospitalizations for myocardial infarction in Italy in the COVID19 era. Eur Heart J. https://doi.org/10.1093/eurheartj/ehaa409

2. Hammad TA, Parikh M, Tashtish N et al (2020) Impact of COVID-19 pandemic on ST-elevation myocardial infarction in a non-COVID-19 epicenter. Catheter Cardiovasc Interv. https://doi. org/10.1002/ccd.28997

3. World Health Organization (2020) Modes of transmission of virus causing covid-19: implications for IPC precaution recommendations. World Health Organization, Geneva

4. Pranata R, Soeroto AY, Ian H et al (2020) Effect of chronic obstructive pulmonary disease and smoking on the outcome of COVID-19. Int J Tuberc Lung Dis. https://doi.org/10.5588/ijtld .20 .0278

5. Pranata R, Lim MA, Huang I et al (2020) Hypertension is associated with increased mortality and severity of disease in COVID-19 pneumonia: a systematic review, meta-analysis and meta-regression. J Renin Angiotensin Aldosterone Syst 21:147032032092689. https://doi.org/10.1177/1470320320926899

6. Huang I, Pranata R (2020) Lymphopenia in severe coronavirus disease-2019 (COVID-19): systematic review and meta-analysis. J Intensive Care 8:36. https://doi.org/10.1186/s40560-020-00453 $-4$
7. Pranata R, Huang I, Lim MA et al (2020) Impact of cerebrovascular and cardiovascular diseases on mortality and severity of COVID-19—-systematic review, meta-analysis, and meta-regression. J Stroke Cerebrovasc Dis. https://doi.org/10.1016/j.jstrokecer ebrovasdis.2020.104949

8. Huang I, Lim MA, Pranata R (2020) Diabetes mellitus is associated with increased mortality and severity of disease in COVID19 pneumonia-a systematic review, meta-analysis, and metaregression. Diabetes Metab Syndr Clin Res Rev 14:395-403. https ://doi.org/10.1016/j.dsx.2020.04.018

9. Pranata R, Huang I, Lukito AA, Raharjo SB (2020) Elevated $\mathrm{N}$-terminal pro-brain natriuretic peptide is associated with increased mortality in patients with COVID-19: systematic review and meta-analysis. Postgrad Med J. https://doi.org/10.1136/postg radmedj-2020-137884

10. Marijon E, Karam N, Jost D et al (2020) Out-of-hospital cardiac arrest during the COVID-19 pandemic in Paris, France: a population-based, observational study. Lancet Public Heal. https ://doi.org/10.1016/S2468-2667(20)30117-1

11. Baldi E, Sechi GM, Mare C et al (2020) Out-of-hospital cardiac arrest during the Covid-19 outbreak in Italy. N Engl J Med. https ://doi.org/10.1056/NEJMc2010418

12. Hara M, Hayashi K, Hikoso S et al (2015) Different impacts of time from collapse to first cardiopulmonary resuscitation on outcomes after witnessed out-of-hospital cardiac arrest in adults. Circ Cardiovasc Qual Outcomes 8:277-284. https://doi.org/10.1161/ CIRCOUTCOMES.115.001864

13. Goto Y, Funada A, Goto Y (2016) Subsequent shockable rhythm during out-of-hospital cardiac arrest in children with initial non-shockable rhythms: a nationwide population-based observational study. J Am Heart Assoc. https://doi.org/10.1161/ JAHA.116.003589

Publisher's Note Springer Nature remains neutral with regard to jurisdictional claims in published maps and institutional affiliations. 